Biografistyka Pedagogiczna

Rok 4 (2019) $\mathrm{nr} 1$

ISSN 2543-6112; e-ISSN 2543-7399

DOI: $10.36578 /$ BP.2019.04.07

Agata Tymicka*

\title{
Wykorzystanie metody biograficznej w praktyce pracy socjalnej
}

\section{The Use of the Biographical Method in the Practice of Social Work}

\begin{abstract}
Social workers help people in difficult life situations which they cannot overcome despite using their own resources and possibilities. To this end, social workers use various methods and tools in their assistance work. Is it possible, however, for social workers to use scientific methods in their professional activity? What significance can the use of the biographical method have in the social work practice? This article attempts to answer these questions. To this end, the study has been divided into several parts. The first part is the introduction, which also clarifies the key concepts. Then, biography is briefly discussed as a method used in social sciences. The next part indicates the therapeutic dimension that biographical work can bring, which is a kind of introduction to the characterisation of the possibility of using the biographical approach in social work. This arrangement of content has made it possible to conclude that a social worker may use certain elements of the biographical method in the assistance process, as well as draw inspiration from research on the beneficiaries of aid institutions carried out using this method.
\end{abstract}

Key words: biographical method, biographical work, social work, social worker.

* Agata Tymicka (ORCID 0ooo-0oo3-4231-2355) - doktorantka w Instytucie Pedagogiki Katolickiego Uniwersytetu Jana Pawła II, pracownik Ośrodka Pomocy Społecznej wSwarzędzu, kontakt: agata.tymicka@gmail.com. 


\section{Wprowadzenie}

Praca socjalna to zinstytucjonalizowana działalność, polegająca na świadczeniu pomocy tym, którzy z różnych przyczyn nie są zdolni do samodzielnego rozwiązania trudnej sytuacji, w jakiej się znaleźli1. W Polsce działalność ta regulowana jest przede wszystkim przepisami Ustawy $z$ dnia 12 marca 2004 r. o pomocy społecznej. Wspomniany akt prawny definiuje pracę socjalną jako „działalność zawodową mającą na celu pomoc osobom i rodzinom we wzmacnianiu lub odzyskiwaniu zdolności do funkcjonowania w społeczeństwie poprzez pełnienie odpowiednich ról społecznych oraz tworzenie warunków sprzyjających temu celowi" ${ }^{\prime 2}$.

W myśl cytowanych przepisów, zawodowy i instytucjonalny charakter pracy socjalnej świadczy o tym, że mogą ją wykonywać jedynie osoby o odpowiednich kwalifikacjach zawodowych, czyli pracownicy socjalni, zatrudnieni na tych stanowiskach w instytucjach pomocy społecznej. Pomoc, jaką świadczą, winna dokonywać się przy maksymalnym wykorzystaniu możliwości i wartości tkwiących w jednostce oraz jej otoczeniu. Nie chodzi zatem o to, by intensyfikować działania w obszarze „patologii”, ale dokonywać próby wywołania pewnej pozytywnej zmiany w człowieku i jego otoczeniu. Jednocześnie sama osoba potrzebująca w pewnym zakresie kreuje ścieżkę rozwiązań problemu, stosownie do aktualnie odczuwanych potrzeb i możliwości, a pracownik socjalny pełni rolę aktywnego „towarzysza zmiany”, który wskazuje możliwości wyjścia z kryzysu, motywuje i pomaga wybrać najwłaściwszą drogę do rozwiązania problemu.

Pojawienie się pracownika socjalnego w życiu osoby potrzebującej oraz jego działalność w postaci pracy socjalnej nie pozostają bez wpływu na biografię klienta. Niejednokrotnie już na etapie pierwszego spotkania, przy wypełnianiu kwestionariusza rodzinnego wywiadu środowiskowego ${ }^{3}$, pracownik socjalny niejako „wsłuchuje się" w opowieść o życiu i za pomocą rozmowy motywującej może rozpocząć proces zmian w życiu beneficjenta.

1 P. Czarnecki, Praca socjalna, Warszawa 2013, s. 7.

2 Ustawa z dnia 12 marca 2004 r. o pomocy społecznej, Dz.U., 2017, poz. 1769, art. 6, pkt. 12.

3 Więcej na ten temat w: Rozporządzenie Ministra Pracy, Rodziny i Polityki Społecznej $z$ dnia 31 sierpnia 2017 r. w sprawie rodzinnego wywiadu środowiskowego, poz. 1788. 
Jak podaje Dorota Sipińska, metoda biograficzna (czy inaczej badania biograficzne) to analiza różnorodnych biografii zastanych lub celowo pozyskanych", czyli dokumentów o charakterze osobistym, odwołujących się do subiektywnej perspektywy badanych. Przeprowadzanie badań tą metodą polega na korzystaniu z dobrowolnych, czasem spontanicznych wypowiedzi badanych (ustnych lub pisemnych), dotyczących ich życia osobistego i doświadczeń ${ }^{5}$. Przedmiotem metody biograficznej jest zatem zawsze życie konkretnego człowieka, ujęte w ramy narracyjne.

Przywołane powyżej definicje pracy socjalnej i metody biograficznej wskazują na pewne cechy wspólne - w obu przypadkach relacja z odbiorcą polega na pozyskiwaniu subiektywnych informacji o jego doświadczeniach życiowych. Dokonuje się to w dwojaki sposób - świadomie, w celu zdobycia konkretnych informacji o biografii badanego lub spontanicznie, w sposób niewymuszony.

W kolejnych częściach niniejszego opracowania podjęto próbę umiejscowienia metody biograficznej w praktyce pracy socjalnej. W tym celu krótko omówiono możliwości wykorzystania badań biograficznych w naukach społecznych i pedagogicznych, z uwzględnieniem terapeutycznego wymiaru biografii oraz idei badań środowiskowych. Następnie wskazano, w jaki sposób podejście biograficzne może mieć zastosowanie w obszarze praktyki pracy socjalnej. W końcowej części podjęto próbę odpowiedzi na pytania, czy metoda biograficzna (lub jej elementy) może zostać wykorzystana przez pracowników socjalnych w praktycznej pracy z klientem marginalizowanym? Czy badacze wykorzystujący metodę biograficzną mogą czerpać z działań i obserwacji pracowników socjalnych? Poszukiwania odpowiedzi na tak postawione pytania wskazały pewne związki pomiędzy omawianymi zagadnieniami.

\section{Badania biograficzne w naukach społecznych}

Metoda biograficzna stanowi ważną część badań podejmowanych w naukach społecznych, w dyscyplinach: socjologii, psychologii czy pedagogiki. Za prekursorów badań biograficznych w socjologii uważa się Williama I. Thomasa i Floriana

4 D. Sipińska, Metoda biograficzna, w: Encyklopedia pedagogiczna XXI wieku, t. 3, Warszawa 2006, s. 156.

5 M. Łobocki, Metody i techniki badań pedagogicznych, Kraków 2007, s. 296. 
Znanieckiego, którzy w latach 1918-1920 dokonali analizy listów i autobiografii polskich emigrantów ${ }^{6}$. Mimo że autorzy nie używali pojęcia "metoda biograficzna", zapoczątkowali rozwój tego podejścia, wskazując, iż materiały biograficzne umożliwiają głęboki wgląd w osobiste doświadczenia badanych. Szczególny rozwój badań biograficznych w socjologii zauważalny jest od lat siedemdziesiątych XX w. ${ }^{7}$, za sprawą Jana Szczepańskiego, który na podstawie analizy dokumentów osobistych opisywał „subiektywną stronę życia społecznego"8. Kontynuatorami podejścia biograficznego w tej dziedzinie są na przykład: Kazimierz Frieske zajmujący się szczególnie badaniem historii życia osób uzależnionych i zmarginalizowanych ${ }^{9}$ oraz Elżbieta Tarkowska badająca biografie ubogich ${ }^{10}$.

W pedagogice natomiast teoretyczne podstawy badań biograficznych opisali między innymi Mieczysław Łobocki i Tadeusz Pilch ${ }^{11}$. Ponieważ w tej dyscyplinie istotne jest nie tylko poznanie, ale przede wszystkim wynikające z poznania działanie, metoda biograficzna znajduje na tym gruncie szczególne zastosowanie. Pozwala bowiem na wielostronną interpretację rzeczywistości wychowawczej, identyfikowanie trudności i właściwe im przeciwdziałanie ${ }^{12}$.

Szczególne znaczenie dla praktyki pracy socjalnej mają badania biograficzne prowadzone na gruncie polityki społecznej. Nieoceniony wkład w rozwój badań biograficznych i badań w działaniu ma szczególnie Marek Rymsza. Autor pod-

6 Teoria socjologiczna Floriana Znanieckiego a wyzwania XXI wieku, red. E. Hałas, Lublin 1999.

7 B. Jonda, R. Sackmann, Koherencja badań biograficznych i analiz biegu życia. Tradycje. Perspektywy. Metody, w: Badania biograficzne i narracyjne w perspektywie interdyscyplinarnej. Aplikacje. Egzemplifikacje. Dylematy metodologiczne, red. M. Piorunek, Poznań 2006, s. 17-43.

8 J. Szczepański, Metoda dokumentów autobiograficznych w naukach społecznych, „Kultura i Społeczeństwo”, 1970, nr 1.

9 Marginalność i procesy marginalizacji, red. K. Frieske, Warszawa 1999; Narkomania. Interpretacje problemu spotecznego, red. K. Frieske, R. Sobiech, Warszawa 1987.

10 Biedni o sobie i o swoim życiu, red. E. Tarkowska, W. Warzywoda-Kruszyńska, K. Wódz, Katowice 2003; Zrozumieć biednego. O dawnej i obecnej biedzie w Polsce, red. E. Tarkowska, Warszawa 2000.

11 Por. M. Łobocki, Metody i techniki badań pedagogicznych, Kraków 2007; T. Pilch, Zasady badań pedagogicznych, Warszawa 1995.

12 P. Kowolik, Badania pedagogiczne opierające się na metodzie biograficznej, „Nauczyciel i Szkoła", 2001, nr 3-4 (12-13), s. 115-121. 
kreśla wagę nie tylko badań nad osobami w trudnych sytuacjach życiowych, ale także nad pracownikami pomocy społecznej, aby nie pozostawali jedynie urzędnikami administracji publicznej, ale byli aktywnymi promotorami pozytywnych zmian w środowisku ${ }^{13}$.

Badania biograficzne przeprowadzane są różnorodnymi technikami, jednak ich celem wspólnym jest analiza przebiegu życia jednostki z różnych perspektyw: osobistej, społecznej, zawodowej ${ }^{14}$.

W naukach społecznych metodę biograficzną stosuje się na dwa sposoby: w pierwszym biografia stanowi przedmiot badań sam w sobie, natomiast badacz analizuje sekwencje w życiu narratora; w drugim - biografia jest niejako środkiem do uzyskania odpowiedzi na ogólne pytani, dotyczące różnych sfer ludzkich działań ${ }^{15}$. Omawiana metoda nie służy zatem jedynie do porządkowania źródeł w celu opisania życia jednostki znanej i wybitnej. W obszarze nauk społecznych badania biograficzne mogą dotyczyć każdego, także osób marginalizowanych.

Danuta Lalak, analizując podejście biograficzne, stawia tezę, iż wykorzystanie perspektywy biograficznej w naukach społecznych uaktywnia trend czyniący historię życia człowieka nie tyle przedmiotem badań i źródłem wiedzy o człowieku, ile przede wszystkim podmiotem zmiany indywidualnej czy społecznej ${ }^{16}$. Zgodnie z tym stwierdzeniem, prowadzenie rzetelnych badań jakościowych w obszarze nauk społecznych winno dokonywać się w kontekście naturalnych warunków funkcjonowania człowieka - w jego środowisku. Stanisław Rychliński postuluje o aktywne zaangażowanie badaczy w rzeczywistość, przestrzega zaś przed oderwaniem badań naukowych od trudności życia codziennego ${ }^{17}$. Badania biograficzne powinny mieć zatem wymiar praktyczny,

13 Pracownicy socjalni i praca socjalna $w$ Polsce. Między służbq społeczna a urzędem, red. M. Rymsza, Warszawa 2012; Reintegracja. Aktywna polityka społeczna w praktyce, red. M. Rymsza, A. Karwacki, T. Kaźmierczak, Warszawa 2014.

14 A. Całek, Biografia naukowa: od koncepcji do narracji. Interdyscyplinarność, teorie, metody badawcze, Kraków 2013, s. 207.

15 A. Golczyńska-Grondas, Ł. Dunajew-Tarnowska, Wprowadzenie, w: Metoda biograficzna $w$ doradztwie zawodowym i pracy socjalnej, red. A. Golczyńska-Grondas, Ł. Dunajew-Tarnowska, Łódź 2006, s. 9.

16 D. Lalak, Życie jako biografia. Podejście biograficzne w perspektywie pedagogicznej, Warszawa 2010, s. 79.

17 S. Rychliński, Lustracje społeczne, Warszawa 2001, s. 25. 
co oznacza konstruowanie problemów badawczych jako poszukiwanie odpowiedzi na aktualnie odczuwane potrzeby społeczne, a stawiane wnioski winny otwierać pole do rekomendacji pozytywnych zmian.

\section{Terapeutyczny wymiar biografii}

Metoda biograficzna może służyć do realizacji celów wychowawczych, edukacyjnych i terapeutycznych. Poznawanie biografii jednostek może stanowić materiał dydaktyczny i wychowawczy poprzez kreowanie pozytywnych wzorców do naśladowania. Wymiar terapeutyczny może mieć natomiast autobiografia, czyli refleksja nad własną biografią, uczenie się z przypomnianych doświadczeń ${ }^{18}$, poprzez swoiste „opowiadanie życia”.

Autobiografia, jako tworzenie narracji o historii życia, jest procesem ciągłym w biegu życia. Ukazuje bowiem trajektorię biografii z trzech perspektyw: przeszłości, teraźniejszości oraz stosunku badanego do przyszłości. Autobiografia jest o tyle specyficzną metodą, że wnioski, jakie zostają postawione w toku badań, mają wartość jedynie w danym momencie. Na każdym kolejnym etapie życia badanego, perspektywa będzie inna - umieszczona w innym, nowym kontekście zdarzeń, uzupełniona o nowe doświadczenia ${ }^{19}$. Należy także dodać, że osoba badacza, jako pojawiająca się na pewnym etapie życia badanego, także ma wpływ na jego biografię. Podobnie badacz nabywa wiedzę i doświadczenie $\mathrm{z}$ tego swoistego spotkania.

Autobiografia nie jest jedynie opisem przeszłości jednostki. Spisanie czy opowiedzenie historii swojego życia (lub jej części) zawsze otwiera drogę do pewnej autorefleksji nad minionymi wydarzeniami i zawiązanymi relacjami. Bez wątpienia zdarzeń dokonanych, czyli przeszłości, nie można zmienić. Warto natomiast zmienić ocenę minionych wydarzeń - i zwykle tak się dzieje, choć nie zawsze celowo i świadomie. Autobiografia może w ten sposób stać się pewnego rodzaju procesem terapeutycznym. Dokonuje się to poprzez samopoznanie, zrozumienie przyczyn danego postępowania, co w konsekwencji prowadzić może do pozytyw-

18 E. Dubas, Uczenie się z (własnej) biografii - wprowadzenie, w: Uczenie się z (własnej) biografii, red. E. Dubas, W. Świtalski, Łódź 2011, s. 13.

19 L. Jakubowska, Uczenie się z biografii. Badania auto/biograficzno-narracyjne, w: Uczenie się z (własnej) biografii, s. 186. 
nej zmiany. Autobiografia to bowiem nie tylko przywoływanie przeżyć z przeszłości, ale przede wszystkim (w tej perspektywie), analiza doświadczeń aktualnych i refleksja nad przyszłością - czyli kształtowanie własnego życia ${ }^{20}$.

Niewątpliwie, narracja autobiograficzna prezentuje subiektywną perspektywę jej narratora. Zatem, w zależności od określonego kontekstu, jednostka może przedstawić niekoniecznie do końca prawdziwą wersję historii. Inna więc może być narracja wewnętrzna i autentycznie przeżywania, inna natomiast opowiedziana i udostępniona innym. Podobnie historia życia klienta pomocy społecznej udostępniona pracownikowi socjalnemu może mijać się z obiektywną prawdą, na co wpływ może mieć na przykład stan emocjonalny - odczuwany wstyd, obawa przed oceną. Z drugiej strony, chęć uzyskania profitów materialnych, czyli zasiłków, może być motywem powodującym przedstawianie zafałszowanej historii.

\section{Podejście biograficzne w pracy socjalnej}

Praca socjalna polega na trwałym przywracaniu zdolności jednostki do prawidłowego funkcjonowania w społeczeństwie. Bez wątpienia jednak, praca nad rozwojem człowieka możliwa jest jedynie wówczas, gdy ma on zapewnione podstawowe potrzeby, czyli elementarne warunki bytowe. Dlatego należy oddzielić pracę socjalną od pomocy finansowej udzielanej z ramienia instytucji pomocy społecznej.

Bezsprzecznie do zakresu obowiązków pracownika socjalnego należy udzielanie zasiłków pieniężnych, co jest ważną częścią pomocy osobom znajdującym się w trudnej sytuacji materialnej. O ile jednak pomoc finansowa pomaga czasowo zabezpieczyć podstawowe potrzeby beneficjenta, o tyle nie niweluje przyczyn trudnej sytuacji i nie przeciwdziała jej nawrotom. Dlatego pracownik socjalny działa wielotorowo - z jednej strony (jeśli pozwalają na to regulacje prawne) prowadzi postępowania dotyczące przyznania pomocy finansowej; $\mathrm{z}$ drugiej natomiast diagnozuje problem w kontekście indywidualnym i społecznym, dokonuje więc analizy przyczyn zastanego zjawiska, poszukuje możliwości rozwiązań w oparciu o zasoby jednostki i społeczeństwa lokalnego.

20 D. Lalak, Życie jako biografia, s. 95-96. 
Wydaje się, że istnieje możliwość wykorzystania podejścia biograficznego w przypadku pracy socjalnej, rozumianej jako działania na fundamentach zasobów i potencjałów tkwiących w jednostce, rodzinie i społeczeństwie. Mylne jest z pewnością przekonanie, że praca socjalna zorientowana jest wyłącznie na działalność z teraźniejszymi wydarzeniami oraz w przyszłości. Pracownik socjalny na początku procesu wsparcia osoby potrzebującej słucha opowieści klienta - czasem o identyfikowanych przez niego przyczynach trudnej sytuacji, emocjach, pragnieniach, a czasem o niemal całym życiu.

Opowieści biograficzne mają w pracy socjalnej zazwyczaj charakter mówiony, choć pewne ich elementy uwzględnione zostają w kwestionariuszu rodzinnego wywiadu środowiskowego ${ }^{21}$. Warto rozróżnić dwa sposoby używania narracji biograficznych w pracy socjalnej. Z jednej strony mogą one stanowić metodę zbierania informacji o kliencie, co jest niezbędne do rozpoczęcia procesu pomocowego, ale także pozwalają lepiej zrozumieć klienta i jego rodzinno-społeczną rzeczywistość. Z drugiej natomiast strony narracje biograficzne same w sobie mogą stanowić pewnego rodzaju narzędzie do wywołania zmian w życiu klienta, budowania jego tożsamości, nadawania alternatywnej interpretacji posiadanym doświadczeniom, a w konsekwencji tworzenia nowej historii życia ${ }^{22}$.

W przypadku, gdy pracownik socjalny wykorzystuje opowieść biograficzną klienta jedynie do zebrania danych niezbędnych do udzielenia pomocy finansowej, opowiedzenie przez jednostkę swojej historii może mieć dla niej znaczenie pozytywne - terapeutyczne. O ile jednak pracownik socjalny nie prowadzi terapii ani w terenie, ani w jednostce pomocy społecznej, o tyle może w swojej pracy wykorzystać pewne jej elementy. Dlatego, jeśli klient utknął w destrukcyjnej narracji, czyli ciągłym skupianiu się na negatywnych elementach swojej biografii, pracownik socjalny może poprzez odpowiednie kierowanie rozmową wpłynąć na proces opowiadania, w ten sposób uzyskując bardziej pozytywną narrację $^{23}$. W efekcie otrzymać można identyfikację przez klienta własnych

21 Rozporządzenie Ministra Pracy, Rodziny i Polityki Społecznej z dnia 31 sierpnia 2017 r., poz. 1788.

22 J. Björkenheim, J. Levälahti, S. Karvinen-Niinikoski, Procesy biograficzne - analiza przypadku $z$ dziedziny pracy socjalnej, w: Metoda biograficzna $w$ doradztwie zawodowym i pracy socjalnej, s. 70.

23 Tamże, s. 71. 
mocnych stron, a niejednokrotnie także, na tej podstawie, sprecyzowanie rzeczywistych potrzeb.

W ocenie autora niniejszego opracowania najistotniejszą zasadą w praktyce pracy socjalnej jest towarzyszenie klientowi w nadawaniu znaczenia jego życiu, nie zaś zastępowanie go w interpretacji doświadczeń i formułowaniu celów. Często jednak pracownik socjalny trafia do środowiska, które nie oczekiwało jego obecności, np. z powodu anonimowego zgłoszenia o zaniedbaniu dzieci. Wówczas negatywne nastawienie jednostki do pracownika, w jego ocenie zbędnej, zakłócającej funkcjonowanie rodziny, utrudnia proces pomocowy, gdyż klient nie identyfikuje swojego działania jako negatywnego, a sytuacji jako problemowej. Istnieją zatem takie przypadki, w których podejście biograficzne używane jest w nieco inny sposób. W sytuacji obrony zaniedbanego dziecka wykorzystanie metody biograficznej może pomóc w określeniu tradycji rodzinnych, zidentyfikowaniu stosowanych przez rodziców metod wychowawczych czy sposobu dziedziczenia stylu wypełniania funkcji opiekuńczo-wychowawczej wobec dziecka ${ }^{24}$. Dopiero po zebraniu tych danych, czyli dokonaniu dogłębnej diagnozy rodziny, metoda biograficzna może służyć jako narzędzie do wywołania pozytywnej zmiany.

Inną formą użycia metody biograficznej w praktyce pracy socjalnej jest praca biograficzna rozumiana jako przekształcenie relacji jednostki z samym sobą. Dokonuje się ona poprzez przywołanie przeszłości, interpretowanie i redefiniowanie zdarzeń na rzecz rozpoczęcia pewnej zmiany ${ }^{25}$. Jednym z przykładów może być badanie biografii samotnych matek, przeprowadzone w $2012 \mathrm{r}$. przez Natalija Mažeikienè i Laura Juodeškaitė. Jak podają autorki, rekonstrukcja historii życia omawianej grupy wytyczyła wspólną trajektorię biograficzną, na którą składały się krytyczne wydarzenia i punkty zwrotne. Biografie ujawniły, że zwykle krytycznym wydarzeniem była nieplanowana ciąża powodująca ukierunkowanie trajektorii na straty w obszarze rodzinnym, utratę bądź

24 K. Gajek, Diagnoza doświadczeń przemocy na podstawie narracji autobiograficznej. Rekomendacje dla orientowania działań upełnomocniajacych, w: Empowerment w pracy socjalnej: praktyka i badania partycypacyjne, red. A. Gulczyńska, M. Granosik, Warszawa 2014; T. Z. Sarleja, Metoda biograficzna w pracy socjalnej, „Nauczyciel i Szkoła", 2003, nr 1-2 (18-19), s. 307-316; J. Szymaniak, Metoda biograficzna w pedagogice, „Studia Gdańskie. Wizje i Rzeczywistośc”, 2013, nr 10.

25 J. Björkenheim, J. Levälahti, S. Karvinen-Niinikoski, Procesy biograficzne, s. 70. 
popsucie relacji z bliskimi. Badania biograficzne ukazały trzy strategie rozumienia oraz interpretacji samotnego macierzyństwa. Pierwsza z nich określona została jako samopoświęcenie, rozumiane jako macierzyńska ofiarność i powołanie, przyczyny trudnej sytuacji upatrywane zaś były w niekorzystnej polityce państwa i trudnej przeszłości badanych. Druga grupa budowała swoją tożsamość poprzez interpretowanie samotnego macierzyństwa jako społecznego niepowodzenia, a częściowo także świadomej decyzji. Ostatnią wyłonioną strategią samotnych matek w budowaniu swojej tożsamości było przeprowadzenie autoanalizy i zinterpretowanie własnego działania w odniesieniu do innych. W tej grupie samotne matki podkreślały, że praca biograficzna pomogła im przetrwać trudne chwile, natomiast wsparcie bliskich i profesjonalistów wzmacniało zdolność do radzenia sobie z przykrymi sytuacjami ${ }^{26}$.

Wyodrębnione strategie radzenia sobie z samotnym macierzyństwem pokazują, że uczestniczki badania najczęściej skupiały się na bolesnych doświadczeniach z przeszłości. Autorki podkreślają, że istotnym aspektem pracy socjalnej z samotnymi matkami może być tworzenie przestrzeni nie tylko do refleksji, ale także do przepracowania skutków przykrych zdarzeń z przeszłości, by móc przezwyciężyć dotychczas przyjmowane nieskuteczne strategie radzenia sobie z macierzyństwem. Uzyskane historie odzwierciedlają wspólne przeżycia samotnych matek, które jako zbiorowe doświadczenia mogą dać pracownikom socjalnym podstawę do współpracy z przedstawicielami polityki społecznej w zakresie udoskonalania programów wsparcia dla tej grupy odbiorców ${ }^{27}$. Jest to wyjątkowo ważne, gdyż w tym przypadku pomoc nie dotyczy jedynie kobiet, ale także ich dzieci, których życie rozpoczęło się w wyniku wspomnianych wydarzeń w historii swoich matek.

\section{Podsumowanie}

Biografia jako rekonstrukcja przeszłości człowieka i nadanie minionym wydarzeniom nowych znaczeń jest z założenia subiektywna, wyraża wewnętrzny świat przeżyć i towarzyszących im emocji. Jednak te subiektywne odczu-

26 N. Mažeikienė, Narracyjna analiza biografii jako narzędzie upetnomocnienia (empowerment), w: Empowerment w pracy socjalnej, s. 62.

27 Tamże, s. 63. 
cia i doświadczenia zawsze osadzone są w szerszym kontekście społecznym, ponieważ człowiek zawsze żyje w mniej lub bardziej intensywnych relacjach z innymi. Dlatego narracja biograficzna, mimo iż z założenia jest subiektywna, w sposób pośredni i bezpośredni ujawnia procesy społeczne określane przez pryzmat podmiotowości. Bezustanna interferencja człowieka i obiektywnej rzeczywistości niejako tworzy procesy społeczne, ale jednocześnie ukazuje znaczenie podmiotowości. Uczestnicy badań biograficznych ujawniają w ten sposób zbiorowe doświadczenia. Badania biograficzne cechuje także pewnego rodzaju niepowtarzalność, człowiek nabywa nowe doświadczenia na każdym etapie swojego życia. Dlatego wynik dziś uzyskany, może nie mieć potwierdzenia w dniu kolejnym, gdyż z każdą godziną przeszłość ubogacana jest nowymi doświadczeniami i interakcjami.

Wobec tak rozumianego podejścia biograficznego pracownik socjalny wykorzystuje je w złożony sposób: może bowiem pracować z klientami tak, by zdobywali nie tylko pomoc finansową, ale przede wszystkim możliwość rozumienia własnej biografii, kontrolowania życia i procesów w nim zachodzących, a w efekcie określania realnych celów i pragnień. Wydaje się zatem, że praca socjalna, będąc działalnością skierowaną ku odzyskiwaniu możliwości prawidłowego funkcjonowania w społeczeństwie, w pewien sposób związana jest z pracą biograficzną. W obu przypadkach chodzi o stworzenie przestrzeni do autorefleksji człowieka nad dotychczasowym postępowaniem, a w konsekwencji przekształcania swojego losu tak, by być aktywnym aktorem własnego życia. Pracownik socjalny powinien wzmacniać w kliencie poczucie mocy sprawczej, nawet w najtrudniejszych sytuacjach, wydających się bez wyjścia.

Jednocześnie pracownik socjalny, wykorzystując podejście biograficzne, może dokonać dokładnej diagnozy potencjału tkwiącego nie tylko w człowieku, ale także jej otoczeniu (rodzinie) i społeczności lokalnej. Jedynie bowiem wnikliwa i rzetelna diagnoza daje podstawę do zaplanowania efektywnych działań pomocowych. Przed pracą socjalną zawsze stoi wyzwanie wywołania pozytywnej zmiany nie tylko w osobie, ale także całej społeczności zmarginalizowanej. Pracownicy socjalni, poprzez pracę z różnorodnymi grupami społecznymi oraz jednostkami na każdym etapie życia, towarzysząc w poszukiwaniu rozwiązań ich problemu, mogą w efekcie przeciwdziałać zjawiskom ogólnospołecznym takim jak ubóstwo, uzależnienia czy rosnące w ostatnim czasie nadmierne zadłużenia gospodarstw domowych. Dzięki obserwacjom i doświadczeniu 
bezpośredniej interakcji z klientem pracownicy socjalni, jako swoiste „ostatnie ogniwo wykonawcze", winni wpływać na całokształt działań polityki społecznej tak, by regulacje prawne oraz realizowane programy były dostosowane do potrzeb odbiorców.

Pracownicy socjalni mogą równocześnie czerpać inspiracje z badań przeprowadzonych przy pomocy metody biograficznej, w celu udoskonalania własnego warsztatu pracy z jednostką potrzebującą. Jednocześnie wydaje się, że badacze biografii osób marginalizowanych mogą także pozyskiwać z doświadczeń pracowników socjalnych podstawy teoretyczne do planowanych działań.

Streszczenie: Pracownicy socjalni zajmują się pomocą osobom znajdującym się w trudnej sytuacji życiowej, której nie są w stanie przezwyciężyć, mimo wykorzystania własnych zasobów i możliwości. W tym celu, w ramach prowadzonej pracy pomocowej, pracownicy socjalni wykorzystują różne metody i narzędzia. Czy możliwe jest jednak, aby pracownik socjalny w swojej zawodowej działalności stosował jednocześnie metody naukowe? Jakie znaczenie może mieć wykorzystanie metody biograficznej w praktyce pracy socjalnej? W niniejszym artykule podjęto próbę odpowiedzi na powyższe pytania. $\mathrm{W}$ tym celu dokonano podziału opracowania na kilka części. Pierwszą z nich stanowi wprowadzenie, uzupełnione o wyjaśnienie kluczowych pojęć. Następnie dokonano krótkiego omówienia biografii jako metody stosowanej w naukach społecznych. W kolejnej części wskazano na terapeutyczny wymiar, jaki może nieść praca biograficzna, co stanowi swoisty wstęp do scharakteryzowania możliwości wykorzystania podejścia biograficznego w pracy socjalnej. Taki układ treści pozwolił na postawienie wniosku, iż pracownik socjalny w procesie pomocowym może stosować pewne elementy metody biograficznej, a także czerpać inspiracje z badań przeprowadzonych tą metodą na beneficjentach instytucji pomocowych.

Słowa kluczowe: metoda biograficzna, praca biograficzna, praca socjalna, pracownik socjalny.

\section{Bibliografia}

Biedni o sobie i o swoim życiu, red. E. Tarkowska, W. Warzywoda-Kruszyńska, K. Wódz, Katowice 2003.

Björkenheim J., Levälahti J., Karvinen-Niinikoski S., Procesy biograficzne - analiza przypadku $z$ dziedziny pracy socjalnej, w: Metoda biograficzna $w$ doradztwie zawo- 
dowym i pracy socjalnej, red. A. Golczyńska-Grondas, Ł. Dunajew-Tarnowska, Łódź 2006, s. 63-86.

Całek A., Biografia naukowa: od koncepcji do narracji. Interdyscyplinarność, teorie, metody badawcze, Kraków 2013.

Czarnecki P., Praca socjalna, Warszawa 2013.

Dubas E., Uczenie się z (własnej) biografii - wprowadzenie, w: Uczenie się z (własnej) biografii, red. E. Dubas, W. Świtalski, Łódź 2011, s. 5-9.

Gajek K., Diagnoza doświadczeń przemocy na podstawie narracji autobiograficznej. Rekomendacje dla orientowania działań upełnomocniających, w: Empowerment w pracy socjalnej: praktyka i badania partycypacyjne, red. A. Gulczyńska, M. Granosik, Warszawa 2014, s. 109-119.

Golczyńska-Grondas A., Dunajew-Tarnowska Ł., Wprowadzenie, w: Metoda biograficzna $w$ doradztwie zawodowym i pracy socjalnej, red. A. Golczyńska-Grondas, Ł. Dunajew-Tarnowska, Łódź 2006, s. 7-12.

Jakubowska L., Uczenie się z biografii. Badania auto/biograficzno-narracyjne, w: Uczenie się z (własnej) biografii, red. E. Dubas, W. Świtalski, Łódź 2011, s. 185-195.

Jonda B., Sackmann R., Koherencja badań biograficznych i analiz biegu życia. Tradycje. Perspektywy. Metody, w: Badania biograficzne i narracyjne w perspektywie interdyscyplinarnej. Aplikacje - Egzemplifikacje - Dylematy metodologiczne, red. M. Piorunek, Poznań 2006, s. 17-43.

Kowolik P., Badania pedagogiczne opierajacce się na metodzie biograficznej, „Nauczyciel i Szkoła", 2001, nr 3-4 (12-13), s. 115-121.

Lalak D., Życie jako biografia. Podejście biograficzne $w$ perspektywie pedagogicznej, Warszawa 2010.

Łobocki M., Metody i techniki badań pedagogicznych, Kraków 2007.

Marginalność i procesy marginalizacji, red. K. Frieske, Warszawa 1999.

Mažeikienè N., Narracyjna analiza biografii jako narzędzie upełnomocnienia (empowerment), w: Empowerment w pracy socjalnej: praktyka i badania partycypacyjne, red. A. Gulczyńska, M. Granosik, Warszawa 2014, s. 57-66.

Narkomania. Interpretacje problemu społecznego, red. K. Frieske, K. Sobiech, Warszawa 1987.

Pilch T., Zasady badań pedagogicznych, Warszawa 1995.

Pracownicy socjalni i praca socjalna $w$ Polsce. Między służba społeczną a urzędem, red. M. Rymsza, Warszawa 2012.

Reintegracja. Aktywna polityka społeczna w praktyce, red. M. Rymsza, A. Karwacki, T. Kaźmierczak, Warszawa 2014.

Rozporządzenie Ministra Pracy, Rodziny i Polityki Społecznej z dnia 31 sierpnia 2017 r. w sprawie rodzinnego wywiadu środowiskowego, poz. 1788.

Rychliński S., Lustracje społeczne, Warszawa 2001. 
Sarleja T. Z., Metoda biograficzna w pracy socjalnej, „Nauczyciel i Szkoła”, 2003, nr 1-2 (18-19), s. 307-316.

Sipińska D., Metoda biograficzna, w: Encyklopedia pedagogiczna XXI wieku, t. 3, Warszawa 2006.

Szczepański J., Metoda dokumentów autobiograficznych w naukach społecznych, „Kultura i Społeczeństwo", 1970, nr 1.

Szymaniak J., Metoda biograficzna w pedagogice, „Studia Gdańskie. Wizje i rzeczywistość", 2013, nr 10, s. 365-381.

Teoria socjologiczna Floriana Znanieckiego a wyzwania XXI wieku, red. E. Hałas, Lublin 1999. Ustawa z dnia 12 marca 2004 r. o pomocy społecznej, Dz.U. z 2017 r. poz. 1769.

Zrozumieć biednego. O dawnej i obecnej biedzie w Polsce, red. E. Tarkowska, Warszawa 2000. 